\title{
PENGARUH ZAKAT PRODUKTIF BAZNAS KOTA MEDAN TERHADAP PERTUMBUHAN USAHA DAN KESEJAHTERAAN MUSTAHIK DI KECAMATAN MEDAN TIMUR
}

\author{
Dewi Sundari Tanjung \\ Perguruan Tinggi Graha Kirana \\ dewisundari437@gmail.com
}

\begin{abstract}
The purpose of this study was to determine the effect of Zakat, Infaq and Productive Sadaqah on the growth of micro enterprises and mustahiq welfare in Medan City, and also to determine the effect of the growth of micro mustahiq businesses on mustahiq welfare in Medan City. This study belongs to the explanatory or confirmatory research category, which is to get an explanation of the relationships between variables. The object to be investigated / analyzed is the variable productive Islamic charity (ZIS) with micro-business variables and welfare variables mustahik on the Medan BAZDA. This research is a quantitative research that uses an analysis of the SPSS approach. The results showed that Zakat, Infaq and Productive Sadaqah had an effect on the growth of mustahiq micro enterprises in Medan City, whereas Zakat, Infaq and Productive Sadaqah did not affect the welfare of mustahiq in Medan City. The potential of ZIS in Medan City is actually quite large, if they distribute their zakat through the BAZNAS in Medan City, a larger fund will be collected for the benefit of the ummah.
\end{abstract}

Keywords: Productive ZIS, Growth, Welfare, Mustahik, BAZ 


\begin{abstract}
Abstrak
Tujuan penelitian ini adalah untuk mengetahui pengaruh Zakat, Infaq dan Shadaqah Produktif terhadap pertumbuhan usaha mikro dan kesejahteraan mustahiq di Kota Medan, serta juga untuk mengetahui pengaruh pertumbuhan usaha mikro mustahiq terhadap kesejahteraan mustahiq di Kota Medan. Penelitian ini termasuk kategori Penelitian eksplanatori atau confirmatory, yakni ingin mendapatkan penjelasan mengenai hubungan antar variabel. Objek yang akan diteliti/dianalisis hubungannya adalah variabel Zakat Infaq Shadaqah (ZIS) produktif dengan variabel usaha mikro dan variabel kesejahteraan mustahik pada BAZDA Kota Medan. Penelitian ini merupakan penelitian kuantitatif yang menggunakan analisis pendekatan SPSS. Hasil penelian menunjukkan Zakat, Infaq dan Shadaqah Produktif berpengaruh terhadap pertumbuhan usaha mikro mustahiq di Kota Medan, sedangkan Zakat, Infaq dan Shadaqah Produktif tidak berpengaruh terhadap kesejahteraan mustahiq di Kota Medan, adapun pertumbuhan usaha mikro mustahiq tidak berpengaruh terhadap kesejahteraan mustahiq di Kota Medan. Potensi ZIS di Kota Medan sebenarnya cukup besar, apabila mereka menyalurkan zakatnya melalui BAZNAS Kota Medan akan terkumpul dana yang lebih besar bagi kemaslahatan ummat.
\end{abstract}

Kata kunci: ZIS produktif, Pertumbuhan, kesejahteraan, mustahik, BAZ

\title{
PENDAHULUAN
}

Kemiskinan merupakan bahaya besar bagi umat manusia dan tidak sedikit umat yang jatuh peradabannya hanya karena kefakiran. Sabda Nabi ada menyatakan itu mendekati kefukuran. Sarana Pendidikan dan peningkatan usaha mikro merupakan salah satu solusi yang kian digalakkan oleh pemerintah akan tetapi jika pemerintah mau lebih kreatif sebenarnya banyak sekali potensi yang dapat digali, terutama otonomi daerah yang diberi keluasan untuk menggali potensi daerah termasuk sumber -sumber pendanaan atau pembiayaan pembangunan. Salah satu sumber pendanaan yang potensial yaitu dana zakat, infaq dan shadaqah, baik yang dikelola oleh Baznas Provinsi Sumatera Utara maupun Baznas Kota Medan. Untuk mengetahui tingkat kemiskinan Kota Medan. Berikut Grafik Kemiskinan periode 2010-2017 :

Penduduk Miskin Kota Medan 2010-2017 (Ribu Jiwa )

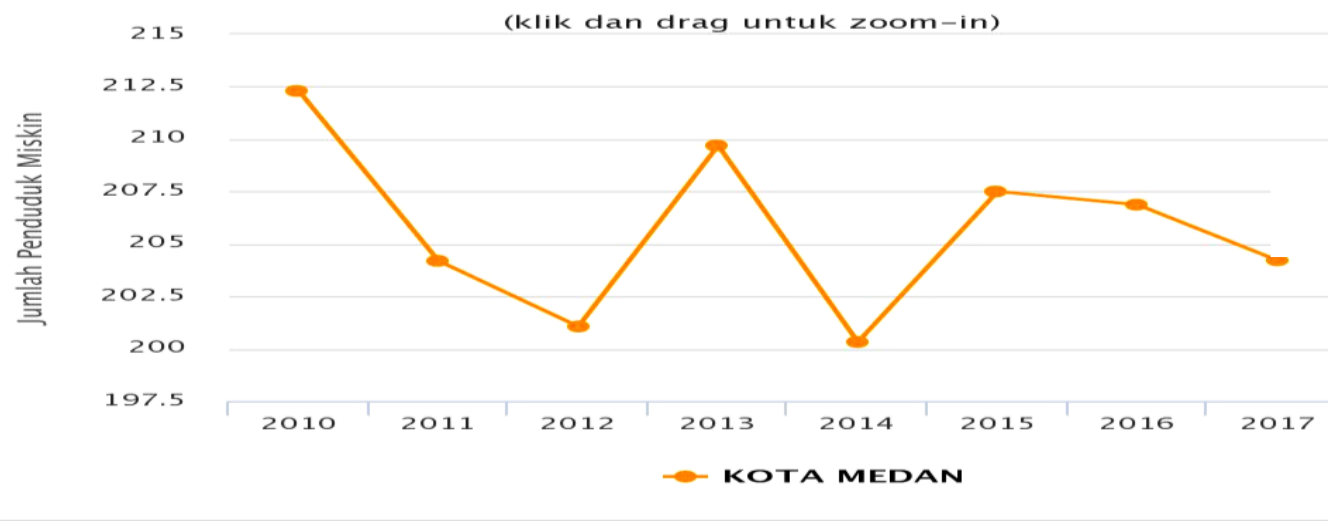




\begin{tabular}{lccccccccc} 
& \multicolumn{8}{c}{ Jumlah Penduduk Miskin di Kota Medan } \\
Kabupaten/Kota & $\mathbf{2 0 1 0}$ & $\mathbf{2 0 1 1}$ & $\mathbf{2 0 1 2}$ & $\mathbf{2 0 1 3}$ & $\mathbf{2 0 1 4}$ & $\mathbf{2 0 1 5}$ & $\mathbf{2 0 1 6}$ & $\mathbf{2 0 1 7}$ \\
& & Jumlah Penduduk Miskin (Ribu Jiwa) & \\
KOTA MEDAN & 212.30 & 204.19 & 201.06 & 209.69 & 200.32 & 207.50 & 206.87 & 204.22 \\
Sumber: medan kota.bps.go.id & & & & & &
\end{tabular}

Penanggulangan sosial ekonomi, menjadi bahan kajian yang selalu menarik di ranah akademik. Dalam pencapaian prioritas nasional untuk menanggulangi kemiskinan, instrumen ZIS (zakat, infaq dan shadaqah) ke depan dituntut untuk semakin berperan dalam mengentaskan kemiskinan dan membawa kesejahteraan kepada masyarakat banyak. Sampai sekarang harus diakui pengumpulan zakat belum maksimal di negara kita. Seperti hal yang disampaikan oleh Direktur Pemberdayaan Zakat Kementerian Agama menyampaikan bahwa potensi zakat pada tahun 2016 sebesar Rp. 217 triliun per tahun, belum lagi jika ditambah dengan infaq, shadaqah dan wakaf. Pada kenyataannya saat ini baru tergali sebesar Rp 3,7 triliun per tahun, ini menunjukan bahwa dana zakat yang berhasil dihimpun dari masyarakat masih jauh dari potensi yang sebenarnya. Hal ini disebabkan belum efektifnya lembaga zakat yang menyangkut aspek pengumpulan, administrasi, pendistribusian, monitoring serta evaluasinya. Namun kita bersyukur hingga saat ini dana zakat yang terhimpun telah mampu membantu lebih dari 2,8 juta mustahik atau lebih dari 9\% orang miskin di Indonesia. Maka bisa dibayangkan seandainya zakat yang terhimpun sampai 10,30, atau 50 persen, niscaya akan menjadi kekuatan yang signifikan untuk mengatasi masalah kemiskinan dan akan banyak memberikan kesejahteraan kepada masyarakat di tanah air Realisasi penerimaan zakat yang masih rendah dibandingkan potensinya, serta masih terkonsentrasi pada satu jenis zakat fitrah, mengindikasikan bahwa terdapat permasalahan- permasalahan yang menyebabkan seorang muslim yang telah mempunyai harta yang cukup untuk wajib zakat tidak patuh dalam dalam berzakat. Pada sisi yang lain mengungkapkan bahwa dalam kenyataannya masyarakat belum memahami secara utuh tentang ajaran zakat.

Penyaluran Zakat Produktif Tahun 2016-2017

\begin{tabular}{|l|l|r|r|l|r|}
\hline No & Jenis usaha & $\begin{array}{c}\text { Jumlah yang } \\
\text { Disetujui }\end{array}$ & $\begin{array}{l}\text { Pendapatan } \\
\text { Perhari }\end{array}$ & $\begin{array}{l}\text { Perdapata } \\
\text { Perbulan }\end{array}$ & $\begin{array}{l}\text { Keuntungan } \\
\text { Bersih }\end{array}$ \\
\hline 1 & Jualan Jajanan/Jus & $8.000 .000,-$ & $1.100 .000,-$ & $30.000 .000,-$ & $12.000 .000,-$ \\
\hline 2 & $\begin{array}{l}\text { Kedai kopi, } \\
\text { lontong/ayat penyet }\end{array}$ & $8.000 .000,-$ & $500.000,-$ & $15.000 .000,-$ & $5.000 .000,-$ \\
\hline 3. & Kantin/Minuman & $8.000 .000,-$ & $1000.000,-$ & $30.000 .000,-$ & $10.000 .000,-$ \\
\hline
\end{tabular}




\begin{tabular}{|l|l|r|r|r|r|}
\hline & Caf & & & & \\
\hline 4. & Jajanan instanl & $4.000 .000,-$ & $2.000 .000,-$ & $60.000 .000,-$ & $6.000 .000,-$ \\
\hline 5. & Jus TM & $7.000 .000,-$ & $1000.000,-$ & $30.000 .000,-$ & $4.500 .000,-$ \\
\hline 6. & Warung Sate /Tahu & $5.000 .000,-$ & $400.000,-$ & $12.000 .000,-$ & $3000.000,-$ \\
\hline 7. & Dagang baju & $10.000 .000,-$ & $3.000 .000,-$ & $90.000 .000,-$ & $3.000 .000,-$ \\
\hline 8. & Kedai Kelontong & $5.000 .000,-$ & $2.000 .000,-$ & $60.000 .000,-$ & $6.000 .000,-$ \\
\hline 9. & Kantin & $6.000 .000,-$ & $300.000,-$ & $9.000 .000,-$ & $2.000 .000,-$ \\
\hline 10. & Warung Makan & $8.000 .000,-$ & $1.000 .000,-$ & $30.000 .000,-$ & $6.000 .000,-$ \\
\hline
\end{tabular}

Sumber : Baznas Kota Medan

\section{KAJIAN TEORI}

\section{Zakat Produktif}

Zakat adalah istilah Al-Quran yang menandakan kewajiban khusus memberikan sebagian kekayaan individu untuk amal kepada yang berhak menerimanya dengan syarat yang telah ditentukan ${ }^{1}$. Sedangkan menurut bahasa berarti keberkahan, pertumuhan dan perkembangan, kesucian. Dalam alqur'an kata zakat tercantum dalam perintah Allah SWT Surat at- Taubah ayat 103. Tujuan dari adanya zakat ini tidak sekedar untuk menyantuni simiskin dengan cara konsumtif akan tetapi juga harus dampak lebih jangka panjang. ${ }^{2}$

Pemanfaatan zakat selama ini dapat digolongkan ke dalam dua kategori, yaitu Zakat Konsumtif dan Zakat Produktif contohnya adalah untuk membangun proyek sosial atau menambah modal pedagang pengusaha kecil. Pendistribusian zakat produktif tradisional dan zakat produktif kreatif sangat perlu dikembangkan karena pendayagunaan zakat yang demikian sangat medekati hakikat zakat, baik yang terkandung dalam fungsinya sebagai ibadah maupun dalam kedudukannya sebagai dana masyarakat. ${ }^{3}$

\section{Pengelolaan Zakat Produktif}

Penyaluran dan pendistribusi dan zakat bisa melalui berbagai cara. Ada yang di distribusikan secara mandiri dan ada pula yang melalui lembaga amil zakat yang ada di sekitarnya dalam hal ini Badan Amil Zakat Nasional (BAZNAS) maupun Badan Amil Zakat Daerah (BAZDA). Sedangkan distribusi

${ }^{1}$ Didin Hafinuddin, Zakat Dalam Perekonomian Modern ( Jakrata : Gema Insani, 2012), h. 7

${ }^{2}$ Abdurrhaman, Qadir, Zakat ( Dalam Dimensi Mahdah dan Sosial), Jakrata , Raja Grafindo, Persada, 2001 ) ha. 30

${ }^{3}$ Mohammad Daud Ali, Sistem Ekonomi Islam, Jurnal Zakat dan Wakaf, h. 62-63. 
zakat secara mandiri banyak di jumpai di berbagai tempat. Terlepas apa motivasi mereka akan tetapi model seperti ini banyak dilakukan oleh para kaum berada untuk menyisihkan harta bendanya bagi kaum duafaee di sekitarnya. Namun, banyak pula kita temui distribusi zakat secara mandiri ini dapat mengakibat kepiluan dan keresahan dan bahkan sampai menelan korban dari para calon mustahik. Karena harus berdesakan dan antri sebelum mereka mendapatkan haknya.

Zakat yang dikelola secara produktif, yang dilakukan dengan cara pemberian modal usaha kepada fakir dan miskin sebagai penerima zakat dan kemudian dikembangkan, untuk memenuhi kebutuhan hidup mereka pada masa yang akan datang. Produktivitas mengandung pengertian filosofi dan definisi kerja. Secara filosofis, produktivitas merupakan pandangan hidup dan sikap mental yang selalu berusaha untuk meningkatkan mutu kehidupan. Keadaan hari ini harus lebih baik dari kemarin dan mutu kehidupan besok harus lebih baik dari hari ini dan seterusnya. Jumlah zakat produktif yang diberikan kepada mustahik akan digunakan sebagai modal usaha. Faktor modal memiliki peranan penting dalam menjalankan kegiatan produksi dan pengembangan usaha. Semakin besar jumlah zakat produtif yang diterima mustahik, maka skala yang dihasilkan semakin besar pula sehingga akan berpengaruh terhadap pada produktivitas mustahik. ${ }^{4}$

\section{Usaha Mikro}

Berdasarkan ukurannya, usaha yang ada di masyarakat dapat dikelompokkan menjadi tiga jenis, yaitu Usaha Mikro (UMi), Usaha Kecil (UK), Usaha Menenga (UM) dan Usaha Besar (UB). "Usaha Mikro" merupakan perluasan kategori rentang jenis usaha supaya dapat menjangkau seluruh tingkatan jenis usaha yang ada. ${ }^{5}$

Undang-undang No. 20 Tahun 2008 tentang UMKM, bahwa Usaha mikro merupakan usaha produktif yang dimiliki oleh perorangan atau badan usaha perorangan yang memenuhi kriteria Usaha Mikro. Sedangkan usaha kecil adalah usaha ekonomi produktif yang beridiri sendiri, yang dilakukan oleh orang

${ }^{4}$ Iskandar Muda, Muhammad Arfan, Pengaruh Jumlah Zakat Produktif, Umur Produktif Mustahik, Dan Lama Usahamustahik Terhadap Produktivitas Usaha Mustahik, Jurnal Ilmiah Mahasiswa Ekonomi Akuntansi (JIMEKA),Volume.1 No.1, Tahun2016, h.318-326

${ }^{5}$ Tim Peneliti CFISEL, Alternatif Pembiayaan Terhadap UMKM Melalui Pasar Modal di Indonesia, (Jakarta: CFISEL, 2009), h. 13-14. 
perorangan atau badan usaha yang bukan merupakan anak perusahaan atau bukan cabang perusahaan yang dimiliki, dikuasai, atau menjadi bagian baik secara langsung maupun tidak langsung dari usaha menengah atau usaha besar yang memenuhi kriteria usaha kecil sebagaimana dimaksud dalam Undang-Undang ini.

Usaha mikro kecil serta menengah mempunyai tujuan yang sama di masyarakat yaitu untuk menumbuh dan mengembangkan usaha dalamrangka membangun perekonomian negara. Kriteria Usaha Mikro yang sebagaimana diatur dalam undang-undang adalah sebagai berikut:

a) Memiliki kekayaan bersih paling banyak Rp. 50.000.000 tidak termasuk tanah dan bangunan tempat usaha.

b) Memiliki hasil penelitian penjualan tahunan paling banyak Rp. 300.000.000.

Dalam prioritas Pembangunan Jangka Panjang, ada beberapa perencanaan pembangunan yang berkitan dengan UMKM. RPJM pada tahun 2015-2019 ditujukan untuk memantapkan pembangunan secara menyeluruh di berbagai bidang dengan menekankan pencapaian daya saing kompetitif perekonomian berlandaskan keunggulan sumberdaya alam dan sumberdaya manusia berkualitas dan kemampuan iptek yang semakin meningkat.

Dengan adanya hal tersebut, maka dikeluarkanlah undang-undang tentang pemberdayaan UMKM, yaitu Undang-undang No.20 Tahun 2008 yang memuat kebijakan berikut: ${ }^{6}$

a. Mengembangkan Usaha Mikro, Kecil, dan Menengah dan Koperasi untuk memberikan kontribusi yang signifikan terhadap pertumbuhan ekonomi, penciptaan lapangan kerja, dan peningkatan daya saing. Sedangkan pengembangan usaha mikro diarahkan untuk memberikan kontribusi dalam peningkatan pendapatan kelompok masyarakat berpendapatan rendah.

b. Memperkuat kelembagaan dengan menerapkan prinsip-prinsip tata kepemerintahan yang baik dan berwawasan gender 
Dewi Sundari Tanjung: Pengaruh Zakat Produktif Baznas Kota Medan |355

c. Memperluas basis dan kesempatan berusaha serta menumbuhkan wirausaha baru yang berkeunggulan untuk mendorong pertumbuhan, peningkatan ekspor, tenaga dan penciptaan lapangan kerja,

\section{Pertumbuhan Usaha}

Pertumbuhan atau perkembangan usaha adalah suatu bentuk usaha kepada usaha itu sendiri agar dapat berkembang menjadi lebih baik lagi dan agar mencapai pada suatu titik atau puncak menuju kesuksesan. Perkembangan usaha dilakukan oleh usaha yang sudah mulai terproses dan terlihat ada kemungkinan untuk menjadi usaha yang lebih maju lagi.

Menurut Hastuti untuk melihat pertumbuhan industri kecil termasuk usaha mikro adalah dengan melihat pertumbuhan usaha. ${ }^{7}$ Perkembangan usaha menurut Purdi E. Chandra adalah suatu keadaan terjadinya peningkatan omset penjualan. Sedangkan menurut Jeaning Beaver yang dikutip dalam Muhammad Sholeh, yang menjadi tolok ukur tingkat keberhasilan dan perkembangan peruahaan kecil dapat dilihat dari peningkatan omset penjualan. Tolok ukur perkembangan usaha haruslah merupakan parameter yang dapat diukur sehingga jika diamati parameter tersebut tidak bersifat maya yang sulit untuk dapat dipertanggung jawabkan.

\section{Kesejahteraan}

Dalam konteks kesejahteraan, "catera” adalah orang yang sejahtera, yakni orang yang dalam hidupnya bebas dari kemiskinan, kebodohan, ketakutan, atau kekhawatiran sehingga hidupnya aman dan tentram, baik lahir maupun batin. ${ }^{8}$

Kesejahteraan selalu dikaitkan dengan materi, dimana semakin tinggi produktivitas maka pendapatan yang dihasilkan pun akan semakin tinggi. Ukuran tingkat kesejahteraan lainnya jugadapat dilihat dari non materi seperti yang dikatakan oleh Pratama dan Mandala melalui tingkat pendidikan, kesehatan dan gizi, kebebasan memilih pekerjaan dan jaminan masa depan yang lebih baik.

Kesejahteraan menurut al-Ghazali ${ }^{9}$ adalah tercapainya kemaslahatan. Kemaslahatan sendiri merupakan terpeliharanya tujuan syara' (Maqashid al-

\footnotetext{
${ }^{7}$ Hastuti, dkk, Peta Upaya Penguatan Usaha Mikro/ Kecil di Tingkat Pusat Tahun 2003,(Jakarta: Kerjasama Lembaga Penelitian Semeru dengan Kementerian Pemberdayaan Perempuan), h. 30.

${ }^{8}$ Fahrudin,Pengantar Ksejahteraan Sosial, (Bandung : Refika Aditama, 2012) h.8
} 
Syari'ah), dimana manusia tidak dapat merasakan kebahagiaan dan kedamaian batin melainkan setelah tercapainya kesejahteraan yang sebenarnya dari seluruh umat manusia di dunia melalui pemenuhan kebutuhankebutuhan ruhani dan materi. Untuk mencapai tujuan syara' agar dapat terealisasinya kemaslahatan, beliau menjabarkan tentang sumber-sumber kesejahteraan, yakni : terpeliharanya agama, jiwa, akal, keturunan dan harta.

\section{Pandangan Islam Tentang Kesejahteraan}

Dalam UU No. 11 tahun 2009 tentang Kesejahteraan Sosial dijelaskan bahwa kesejahteraan social adalah kondisi terpenuhinya kebutuhan material, spiritual, dan sosial warga negara agar dapat hidup layak dan mampu mengembangkan diri, sehingga dapat melaksanakan fungsi sosialnya. ${ }^{10}$

Kesejahteraan menurut syariah islamiyah adalah telah tercapainya tujuan manusia secara komprehensif ataupun secara menyeluruh sehingga manusia itu telah mencapai kebahagian secara holistic pula (kebahagiaan lahir dan batin, dunia dan akhirat). sistem kesejahteraan dalam konsep ekonomi Islam adalah sebuah sistem yang menganut dan melibatkan faktor atau variabel keimanan (nilai-nilai islam) sebagai salah satu unsur fundamental yang sangat asasi dalam mencapai kesejahteraan Individu dan kolektif sebagai suatu masyarakat atau negara.

Chapra menggambarkan secara jelas bagaimana eratnya hubungan antara Syariat Islam dengan kemaslahatan. Ekonomi Islam yang merupakan salah satu bagian dari Syariat Islam, tentu mempunyai tujuan yang tidak lepas dari tujuan utama Syariat Islam. Tujuan utama ekonomi Islam adalah merealisasikan tujuan manusia untuk mencapai kebahagiaan dunia dan akhirat (falah), serta kehidupan yang baik dan terhormat (al-hayah al-thayyibah). Ini merupakan definisi kesejahteraan dalam pandangan Islam, yang tentu saja berbeda secara mendasar dengan pengertian kesejahteraan dalam ekonomi konvensional yang sekuler dan materialistic. ${ }^{11}$

9 Rohman, Abdur, Ekonomi Al-Ghazali, Menelusuri Konsep Ekonomis Islam dalam Ihya'Ulum al-Din, (Surabaya : Bina Ilmu, 2010), h.53-56

${ }^{10}$ UU No.11 Tahun 2009 Tentang Kesejahteraan Sosial, Bab I ( Ketentuan Umum ) Pasal 1.

${ }^{11}$ Chapra dan M. Umer. The Future of Economics : An Islamic Perspective, Shariee ah Economics and Banking Institute (SEBI), (Jakarta : Kencana, 2001 ) h.333 
Dewi Sundari Tanjung: Pengaruh Zakat Produktif Baznas Kota Medan |357

\section{Teori Pemberdayaan Menurut Chambers}

Keberdayaan ekonomi masyarakat merupakan sebuah konsep pembangunan ekonomi dan politik yang merangkum berbagai nilai sosial. Konsep ini menurut Chambers bahwa mencerminkan paradigma baru pembangunan, yakni bersifat "people centered, participatory, empowering, and sustainable" (berpusat pada rakyat, partisipatoris, memberdayakan, dan keberlanjutan). ${ }^{12}$

Pemberdayaan atau pemberkuasaan berasal dari kata berbahasa Inggris empowerment yang akar katanya yaitu power yang berarti kekusaan atau keberdayaan. Kekuasaan dapat membuat orang lain melakukan apa yang kita inginkan terlepas dari keinginan dan minat mereka. Kakuasaan selalu berkaitan dengan pengaruh dan kontrol. Pemberdayaan selalu merujuk pada kemampuan orang, khususnya kelompok rentan dan lemah sehingga mereka memiliki kekuatan atau kemampuan dalam:

1. Memenuhi kebutuhan dasarnya sehingga mereka mimiliki kebebasan;

2. Menjangkau sumber-sumber yang produktif yang memungkinkan mereka dapat meningkatkan pendapatannya juga dapat memperoleh barang-barang dan jasa yang mereka butuhkan;

3. Berpartisipasi dalam proses pembangunan dan merumuskan keputusankeputusan yang mempengaruhi kehidupan merek.

\section{Penelitian Terdahulu}

Penelitian Jalaluddin mengatakan dalam kesimpulan disertasinya, bahwa ZIS produktif berpengaruh signifikan terhadap kesejahteraan. Hal ini berarti bahwa bantuan modal dari dana ZIS yang diberikan BAZDA Kabupaten Lombok Timur NTB cenderung dapat meningkatkan kesejahteraan para mustahik, dalam arti bahwa semakin besar jumlah bantuan yang diberikan, maka ada kecendrungan tingkat kesejahteraan mustahik yang diukur berdasarkan maqasid syariah dari AsSyatibi juga akan semakin meningkat. Demikian juga sebaliknya semakin semakin kecil jumlah bantuan yang diberikan, maka dampaknya terhadap kesejahteraan mustahik juga cenderungkecil.

\footnotetext{
${ }^{12}$ Robert Chambers, Proverty and Livelihoods: Whose Reality Counts?, Environment and Urbanization, Vol. 7, No. 1, April 1995, hal. 200
} 
Rakhman, Amry dalam disertasinya mengemukakan, bahwa penggunaan ZIS berpengaruh secara signifikan dengan arah positif terhadap kinerja usaha produktif Mustahik di Kabupaten Sumbawa Barat. Keadaan tersebut memberikan makna bahwa semakin banyak penggunaan ZIS untuk usaha produktif, maka semakin besar pengaruhnya dalam memperbaiki kinerja usaha produktif mustahik, sehingga mustahik akan terus meningkatkan penggunaan ZIS dalam membiayai usaha produktifnya. Menurut Syarifuddin bahwa pengeluaran ZIS berpengaruh positif dan signifikan terhadap produktivitas mustahik, kinerja usaha mustahik dan kesejahteraan mustahik, sedangkan menurut Devialina penggunaan ZIS berpengaruh secara signifikan dengan arah positif terhadap pemberdayaan usaha rumah tangga, dan menurut ZIS produktif berpengaruh signifikan terhadap kesejahteraan dibandingkan dengan ZIS Konsumtif kemudian Nova Rini menyatakan bahwa ZIS berpengaruh signifikan terhadap Pendapatan dan kemiskinan.

\section{Kerangka Berfikir}

Kerangka konseptual penelitian ini dapat dibentuk seperti pada gambar berikut :

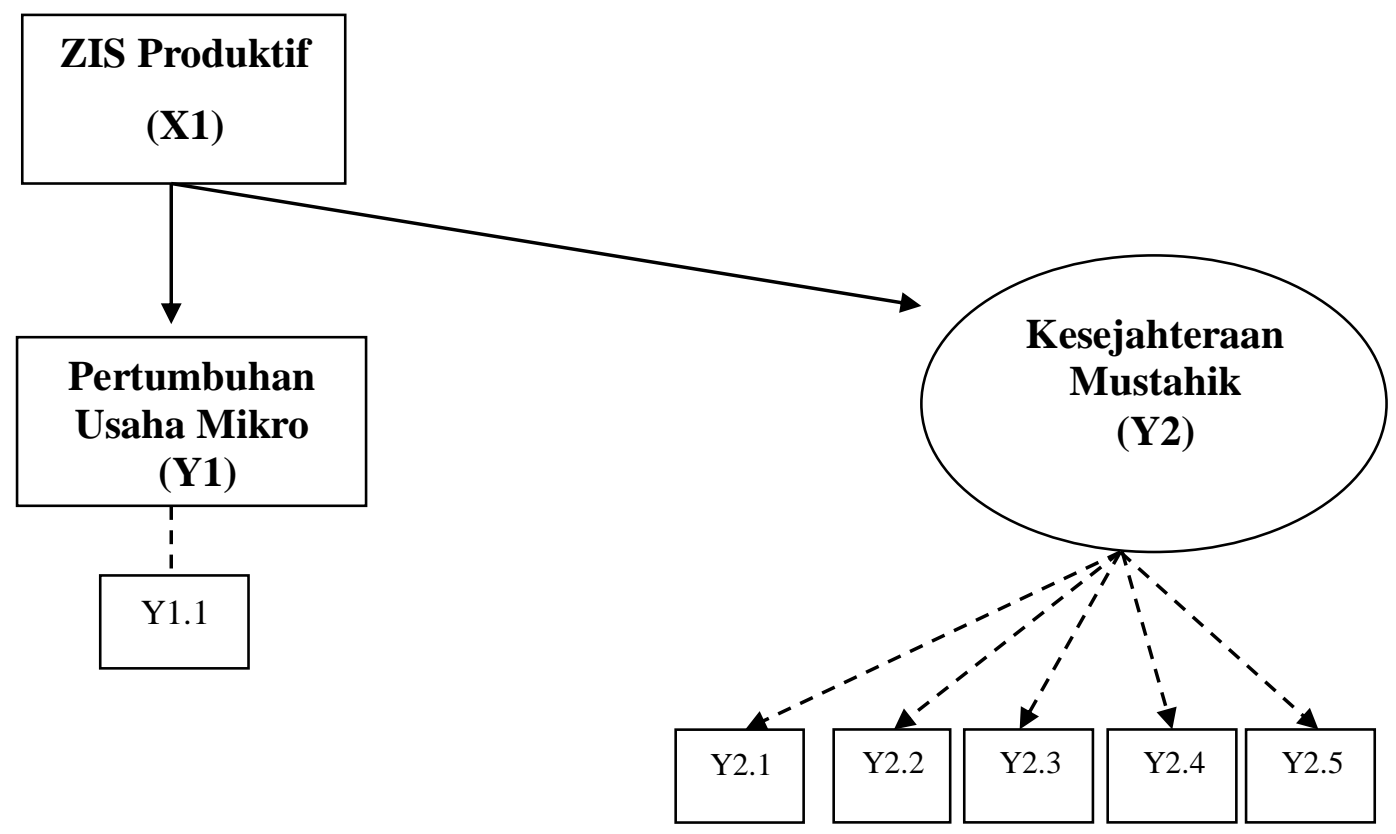

Variabel ZIS produktif dipresentasikan oleh nilai /jumlah bantuan (X). Sedangkan pertumbuhan usaha mikro (Y1) diukur berdasarkan dari perubahan volume 
Dewi Sundari Tanjung: Pengaruh Zakat Produktif Baznas Kota Medan |359

penjualan (Y1.1). Sementara variabel kesejahteraan mustahik (Y2) diukur berdasar maqasid syariah dari As- Syatibi yaitu Dien yang dalam hal ini didekati melalui pelaksanaan sholat (Y2.1), Nafs/jiwa didekati melalui kesehatan/frekuensi dan lama sakit (Y2.2), Aql (intelektual) didekati melalui pendidikan (Y2.3), Nasl (keluarga dan keturunan) didekati melalui keturunan/jumlah anak (Y2.4), dan Mal/harta yang diukur/didekati melalui jumlah pendapatan (Y2.5).

\section{METODE PENELITIAN}

Path analysis digunakan untuk menguji hubungan langsung, tidak langsung dan hubungan total antar variabel bebas dan variabel terikat. Pengolahan data menggunakan program SPSS 22 untuk path analisis. ${ }^{13}$ Pengaruh antara variabel eksogen dan endogen dibagi berdasarkan kompleksitas hubungan variabel, yaitu:

1) pengaruh langsung (direct effects)

a) Pengaruh langsung zakat Produktif terhadap pertumbuhan UKM

$$
\begin{aligned}
& \mathrm{Y} 1=\mathrm{f}\left(\mathrm{X}_{1}\right) \\
& \mathrm{Y} 1=\mathrm{PY} 1 \mathrm{X} 1
\end{aligned}
$$

b) Pengaruh langsung zakat Produktif terhadap kesejahteraan mustahik

$$
\begin{aligned}
& Y 2=f\left(X_{1}\right) \\
& Y 2=P Y 2 X 1
\end{aligned}
$$

2) Pengaruh tidak langsung (indirect effects)

a) Pengaruh tidak langsung zakat produktif terhadap kesejahteraan mustahik melalui pertumbuhan UKM.

$$
\begin{aligned}
& \mathrm{Y}_{2}=\mathrm{f}\left(\mathrm{X}_{1} \mathrm{Y}_{1}\right) \\
& \mathrm{Y}_{2}=(\mathrm{PY} 1 \mathrm{X} 1)(\mathrm{PY} 2 \mathrm{X} 1)
\end{aligned}
$$

3) pengaruh total (total effects)

a) Pengaruh total zakat produktif terhadap kesejahteraan mustahik melalui pertumbuhan UKM.

$\mathrm{Y}_{2}=\mathrm{f}\left(\mathrm{X}_{1} \mathrm{Y}_{1}\right)$

${ }^{13}$ Sugiono, Metode Penelitian Pendidikan, Pendekatan Kuantitatif, Kualitatif Da R\&D, (Bandung, Alfabeta, 2008), h. 124 


$$
\mathrm{Y}_{2}=\mathrm{PY} 1 \mathrm{X} 1+\mathrm{PY} 2 \mathrm{X} 1
$$

Keterangan :

Y1 = Pertumbuhan UKM (Endogenus Variable $)$

Y2 = Kesejahteraan Munasfik (Endogenus Variable)

$\mathrm{X} 1$ = Zakat Produktif (Eksogenus Variable)

$\dot{\varepsilon}=$ Error Term / Tingkat Kesalahan

Pengaruh total merupakan penjumlahan dari pengaruh langsung dan pengaruh tak langsung, sedangkan pengaruh tak langsung adalah perkalian dari semua pengaruh langsung yang dilewati (variabel eksogen menuju variabel endogen/variabel endogen).

\section{HASIL PENELITIAN}

Pada bagian ini analisis dibagi menjadi dua. Pertama, melihat pengaruh secara gabungan dan kedua, melihat pengaruh secara parsial.

1) Melihat pengaruh Zakat produktif secara gabungan terhadap Kesejahteraan .Untuk melihat pengaruh variabel Zakat produktif terhadap Kesejahteraan, kita akan melihat hasil perhitungan dalam model summary, khususnya angka R square berikut ini :

\begin{tabular}{|l|l|l|l|l|}
\hline Model & $\mathrm{R}$ & R Square & $\begin{array}{l}\text { Adjusted } \\
\text { Square }\end{array}$ & $\begin{array}{l}\text { R Std. Error of the } \\
\text { Estimate }\end{array}$ \\
\hline 1 & $318^{\mathrm{a}}$ &, 101 &, 005 &, 72894 \\
\hline
\end{tabular}

a. Predictors: (Constant), Perkembangan usaha, Zakat produktif

b. Dependent Variable: Kesejahteraan

Besarnya angka $\mathrm{R}$ square $\left(\mathrm{R}^{2}\right)$ adalah 0,101 . Angka tersebut mempunyai maksud bahwa pengaruh variabel Zakat produktif terhadap Kesejahteraan secara gabungan adalah 10,1\%, sedangkan sisanya sebesar $89,9 \%(100 \%-10,1 \%)$ dipengaruhi oleh faktor lain.

Tabel anova

\begin{tabular}{|l|l|l|l|l|l|}
\hline Model & Sum of Squares & df & $\begin{array}{l}\text { Mean } \\
\text { Square }\end{array}$ & F & Sig. \\
\hline Regression & 1,675 & 3 &, 558 & 3,309 &, $000^{\mathrm{b}}$ \\
Residual & 14,878 & 28 &, 531 & & \\
Total & 16,553 & 31 & & & \\
\hline
\end{tabular}


Dewi Sundari Tanjung: Pengaruh Zakat Produktif Baznas Kota Medan |361

\begin{tabular}{|l|l|l|l|l|l|}
\hline Model & \multicolumn{2}{|l|}{$\begin{array}{l}\text { Unstandardized } \\
\text { Coefficients }\end{array}$} & $\begin{array}{l}\text { Standardized } \\
\text { Coefficients }\end{array}$ & Tig. \\
\cline { 2 - 4 } & $\mathrm{B}$ & Std. Error & Beta & & \\
\hline \multirow{2}{*}{$\begin{array}{l}\text { (Constant) } \\
1\end{array}$} & 1,883 &, 157 & & 12,332 &, 000 \\
$\begin{array}{l}\text { Zakat produktif } \\
\text { Perkembangan } \\
\text { usaha }\end{array}$ & 151.405 &, 000 &, 333 & 1,925 &, 014 \\
\hline
\end{tabular}

Dependent Variable: Kesejahteraan

Tabel di atas menunjukkan adanya hubungan linier antara zakat produktif dengan kesejahteraan dengan besarnya pengaruh 33,3\% dan ada hubungan linier antara perkembangan usaha dengan kesejahteraan sebesar 0,414 atau 41,4\%.

\begin{tabular}{|ll|l|l|}
\hline & & $\begin{array}{l}\text { Zakat } \\
\text { produktif }\end{array}$ & $\begin{array}{l}\text { Perkembanga } \\
\text { n usaha }\end{array}$ \\
\hline \multirow{2}{*}{ Zakat produktif } & Pearson & 1 & 0,952 \\
& Correlation & & 0,011 \\
& Sig. (2-tailed) & & 32 \\
\hline P & Pearson & 0,952 & 1 \\
& Correlation & 0,011 & \\
& Sig. (2-tailed) & N & 32 \\
\hline
\end{tabular}

Korelasi sebesar 0,952 mempunyai maksud hubungan antara variabel Zakat produktif Perkembangan usaha sangat kuat dan searah (karena hasilnya positif). Searah artinya jika Zakat produktif tinggi maka Perkembangan usaha juga tinggi. Korelasi dua variabel bersifat signifikan karena angka signifikansi sebesar 0,011 <0,05 maka hubungan kedua variabel signifikan.

Untuk menghitung pengaruh langsung atau DE, digunakan formula sebagai berikut:

a) Pengaruh variabel Zakat produktif terhadap Perkembangan usaha $\mathrm{X} 1 \rightarrow \mathrm{Y} 1=$ 0,601

b) Pengaruh variabel Zakat produktif terhadap kesejahteraan $\mathrm{X} 1 \rightarrow \mathrm{Y} 2=0,333$

c) Pengaruh variabel Perkembangan usaha terhadap kesejahteraan $\mathrm{Y} 1 \rightarrow \mathrm{Y} 2=0,414$ 
Untuk menghitung pengaruh tidak langsung atau IDE, di mana pengaruh variabel Zakat produktif terhadap kesejahteraan melalui Perkembangan usaha

$$
\mathrm{X} 1 \rightarrow \mathrm{Y} 1 \rightarrow \mathrm{Y} 2=(0,601 \times 0,414)=0,248814
$$

Sedangkan Pengaruh Total (Total Effect) pengaruh variabel Zakat produktif terhadap kesejahteraan melalui Perkembangan usaha

$$
\mathrm{X} 1 \rightarrow \mathrm{Y} 1 \rightarrow \mathrm{Y} 2=(0,333+0,414)=0,137862
$$

Persamaan struktural untuk model tersebut ialah :

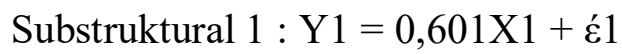

Substruktural $2: \mathrm{Y} 2=0,333 \mathrm{X} 1+0,414 \mathrm{Y} 1+\mathrm{e} 2$

Berasarkan analisis diketahui bahwa ZIS produktif mempunyai pengaruh significant (dalam pengertian predictive relevan) terhadap pertumbuhan usaha mikro mustahik dengan nilai koefisien jalur atau t statistik sebesar 3,033 diatas 1,96, sehingga dikatakan pengaruhnya positif dan signifikan, artinya penambahan dana ZIS produktif berpengaruh signifikan terhadap pertumbuhan usaha mikro mustahik di Medan Timur, ningkatkan penambahan dana ZIS produktif akan meningkatkan pertumbuhan usaha mikro mustahik. Indikasi lain dari signifikannya pengaruh ZIS produktif terhadap pertumbuhan usaha mikro adalah perubahan omset yang diperoleh oleh usaha mikro para mustahik sebelum mendapatkan dana ZIS Produktif dan sesudah mendapatkan dana ZIS produktif.

Berdasarkan analisis diketahui bahwa ZIS produktif mempunyai pengaruh significant (dalam pengertian predictive relevan) terhadap kesejahteraan mustahik. Didasarkan hasil perhitungan, diperoleh angka t penelitian sebesar 1,925 > t tabel sebesar 1,693 sehingga $\mathrm{H}_{0}$ ditolak dan $\mathrm{H}_{1}$ diterima. Artinya ada hubungan linier antara Zakat produktif dengan Kesejahteraan. Besarnya pengaruh Zakat produktif terhadap Kesejahteraan sebesar 0,333 atau 33,3\%. Berpengaruh secara signifikan terhadap kesejahteraan mustahik di Medan Timur Akan tetapi secara deskriftif kita bisa melihat secara umum apabila kita melihat jawaban responden tentang kesejahteraan sudah meningkat.

Hasil studi ini seiring dengan laporan penelitian Lembaga Zakat (2001: 1) yang menyatakan bahwa pengelolaan zakat di Indonesia, baik pengumpulan zakat maupun pemberdayaan dana zakat untuk usaha produktif masih belum mampu memberikan peranan dan pengaruh besar bagi terwujudnya kesejahteraan sosial ekonomi ummat Islam. Padahal, pengelolaan zakat telah ditopang oleh perangkat hukum, yaitu UU no 38 tahun 1999 tentang "Pengelolaan Zakat" dan keputusan 
Menteri Agama Nomor 581 tahun 1999 yang telah diubah dengan keputusan Menteri Agama Nomor 373 Tahun 2003 tentang Pelaksanaan UU Nomor 38 tahun 1999 dan juga pada UU Nomor 23 tahun 2011 tentang Pengelolaan Zakat. Kurang optimalnya keberadaan UU dan peraturan Zakat tersebut disebabkan oleh dua hal yaitu: (1) Sosialisasi dan perangkat UU zakat belum bisa berbuat banyak, sehingga masyarakat belum memahami pemahaman yang baik tentang zakat, dan (2) perangkat pelaksana UU zakat berupa Peraturan Pemerintah atau Keputusan Menteri Agama belum memiliki kekuatan untuk "memaksa" lembaga yang terkait zakat untuk melaksanakan dan melakukan yang ada di dalam UU atau peraturan tersebut.

Berdasarkan hasil analisis data diketahui hasil perhitungan, angka $\mathrm{t}$ penelitian sebesar 2,527>t tabel sebesar 1,693 sehingga $\mathrm{H}_{0}$ ditolak dan $\mathrm{H}_{1}$ diterima. Artinya ada hubungan linier antara Perkembangan usaha dengan Kesejahteraan. Besarnya pengaruh Perkembangan usaha terhadap Kesejahteraan sebesar 0,414 atau 41,4\%. Kondisi ekonomi dunia yang terjadi saat ini menunjukkan penurunan ekonomi di belahan dunia, ini bisa dilihat dari laporan triwulan 2014 yang dikeluarkan Bank Dunia (World Bank, 2014) yang memproyeksi penurunan pertumbuhan ekonomi di Amerika, Eropa, Jepang dan negara-negara berkembang di belahan dunia. China Sebagai negara yang pertumbuhan ekonomi selalu tumbuh pun harus menyeimbangkan ekonominya yang berdampak pada perlambatan laju pertumbuhan ekonomi. Kondisi perekonomian dunia diatas berdampak juga dengan laju pertumbuhan ekonomi di Indonesia melambat yang dipengaruhi oleh perlemahan investasi dan ekspor. Perlambatan pertumbuhan ekonomi menandakan adanya penurunan aktivitas ekonomi yang tentunya akan berdampak pada pertambahan angka kemiskinan, khususnya di negara- negara berkembang, termasuk Indonesia. Laju pertumbuhan ekonomi Indonesia yang relatif lambat dibandingkan dengan beberapa tahun yang lalu diperkirakan akan memperlambat laju penurunan tingkat kemiskinan nasional, yang pada bulan Maret 2014 berada pada angka 11,3 persen. Indonesia menghadapi tantangan-tantangan untuk menangani masalah kemiskinan ekstrim yang sulit dipecahkan. Kemiskinan diproyeksikan akan tetap berada di atas 8 persen pada tahun 2018, kecuali terdapat aksi bersama untuk mendukung pemerataan pertumbuhan, memperkuat dan memperluas jaring pengaman sosial. 
Dalam rentang bangsa Indonesia merdeka, kemiskinan masih menjadi masalah utama pembangunan nasional saat ini. Upaya penanggulangan kemiskinan yang telah dicanangkan pemerintah mendapat tantangan yang berat. Beragam program yang digulirkan belum menberikan dampak signifikan dalam menekan angka kemiskinan.

Perekonomian Indonesia secara umum mengalami perlambatan, hal ini bisa dilihat dari pertumbuhan ekonomi tahun 2014 yang hanya 5\%, pada tahun 2019 diperkirakan akan turun menjadi 3,5\%, walaupun pemerintah masih optimis di angka $5 \%$. Tetapi kalau dilihat ekonomi global yang sedang melambat, tentunya akan berpengaruh kepada perekonomian Indonesia secara umum. Hal pelambatan ekonomi Indonesia juga dapat dilihat dari penurunan angka ekspor, menurunnya konsumsi dikarenakan menurunnya daya beli masyarakat yang tentunya berpengaruh pada penurunan investasi, pemutusan negara kerja, menurunnya nilai mata uang rupiah dan kenaikan berbagai harga khususnya harga-harga bahan pokok yang berhubungan dengan pangan. Hal diatas tentunya akan berpengaruh pada angka kemiskinan dan akan berdampak pada tingkat kesejahteraan masyarakat.

Terkait dengan hal tersebut, dan sejalan dengan tujuan utama dari proses pembangunan yaitu meningkatkan kesejahteraan masyarakat baik materiil maupun spirituil secara adil dan merata, maka mau tidak mau kemiskinan harus ditanggulangi. Salah satu upaya yang dapat ditempuh dalam penanggulangan kemiskinan adalah dengan memperdayakan usaha mikro, kecil dan menengah karena usaha ini telah mampu membuktikan diri sebagai landasan perekonomian Indonesia melalui ketahanan diri yang dibuktikan selama krisis melanda Indonesia. Arti penting UMKM tidak terbantahkan lagi karena ia merupakan penyumbang lapangan pekerjaan terbesar perekonomian Indonesia (PDB, 2007). Selain itu usaha mikro merupakan sektor yang diperani oleh sebagian besar mayarakat Indonesia. Demikian pula usaha mikro, kecil, dan menengah (UMKM) pada dasarnya merupakan bagian dari masyarakat miskin yang mempunyai kemauan dan kemampuan produktif.

\section{V.KESIMPULAN}


Zakat produktif mempunyai pengaruh signifikan terhadap pertumbuhan usaha mikro mustahik, artinya penambahan dana Zakat produktif sangat berpengaruh signifikan terhadap pertumbuhan usaha mikro mustahik di Medan Timur , penambahan dana ZIS produktif akan meningkatkan pertumbuhan usaha mikro mustahik. Omset harian yang dihasilkan oleh para mustahik juga meningkat setelah adanya dana Zakat produktif yang disalurkan BAZNAS Medan Timur . Para mustahik dengan modal ZIS tidak menggunakan sistem bunga/riba ${ }^{\text {ee }}$ sehingga membantu mereka terhindar dari rentenir yang mencekik dan menjauhkan mereka dari perbuatan haram dan dosa. Sebelum adanya program ZIS produktif kebanyakan responden mendapatkan modal dari rentenir yang membebankan bunga/riba yang sangat tinggi berkisar 100\%-200\% yang tentunya sangat memberatkan dan membebani para responden serta menimbulkan efek melanggar aturan agama yang melarang adanya bunga/riba.

Zakat produktif mempunyai pengaruh signifikan terhadap kesejahteraan mustahik, artinya penambahan dana Zakat produktif berpengaruh secara signifikan terhadap kesejahteraan mustahik di Medan Timur. Akan tetapi secara deskriftif kita bisa melihat secara umum apabila kita melihat jawaban responden tentang kesejahteraan hasilnya ada peningkatan. Hasil penelitian ini mungkin terjadi dikarenakan minimnya dana Zakat produktif yang disalurkan kepada mustahik, hal lain juga yang menyebabkan tidak signifikannya pengaruh dana Zakat produktif terhadap kesejahteraan mustahik adalah kebutuhan hidup mustahik yang semakin bertambah dan banyak, juga yang mempengaruhi adalah konsep kesejahteraan yang cukup luas yang ada pada konsep kesejahteraan Islam yang meliputi maqosid syariah, yang artinya bukan hanya materi dunia saja yang menentukan, melainkan semua aspek kehidupan dunia akhirat yang meliputi hifdzu din, hifdzu nafs, hifdzu aql, hifdzu nasl, hifdzu maal.

Pertumbuhan usaha mikro mustahik berpengaruh signifikan terhadap kesejahteraan mustahik di Medan Timur, artinya pertumbuhan usaha mikro mustahik berpengaruh secara signifikan terhadap kesejahteraan mustahik di Medan. Akan tetapi secara deskriftif kita bisa melihat secara umum apabila kita melihat jawaban responden tentang kesejahteraan. Hasil penelitian ini terjadi mungkin dikarenakan kecilnya skala usaha mikro mustahik yang hanya kalau kita lihat dari omset harian yang dihasilkan para mustahik sehingga menyebabkan 
keuntungan dari pendapatan yang mereka terima juga menjadi kecil. Disisi lain jumlah tanggungan/anggota rumah tangga yang lumayan besar semakin memperkecil bagian yang diterima perkapita dari jumlah pendapatan yang relatif kecil pula. Dengan demikian walaupun terjadi peningkatan pendapatan namun peningkatan tersebut tidak sebanding dengan jumlah kebutuhan mereka yang harus menghidupi jumlah tanggungan yang lumayan besar, sehingga pengaruh dari adanya peningkatan pertumbuhan usaha mereka yang dicerminkan oleh meningkatnya volume/omset penjualan dan keuntungan belum berpengaruh secara signifikan terhadap kesejahteraan mereka. Juga yang mempengaruhi adalah konsep kesejahteraan yang cukup luas yang ada pada konsep kesejahteraan Islam yang meliputi maqosid syariah, yang artinya bukan hanya materi dunia saja yang menentukan kesejahteraan seseorang, melainkan semua aspek kehidupan dunia akhirat yang meliputi hifdzu din, hifdzu nafs, hifdzu aql, hifdzu nasl, hifdzu maal.

Kesejahteraan bisa diraih oleh siapa saja tak perduli kaya atau miskin, termasuk para mustahik. Karena sesungguhnya kesejahteraan dalam pandangan Islam adalah kesejahteraaan yang holistik dan seimbang, berdimensi dunia akhirat, yang dicerminkan oleh kecukupan materi dan didukung oleh terpenuhinya kebutuhan spiritual serta mencakup individu dan sosial dan bukan diukur dengan keberlimpahan materi yang dimiliki.

\section{DAFTAR PUSTAKA}

Asnaini, Zakat Produktif Dalam Perspektif Hukum Islam, Yogyakarta : Pustaka Pelajar, 2012.

Anwar, Ahmad Thoharul. "Zakat Produktif Untuk Pemberdayaan Ekonomi Ummat”, Jurnal ZISWAF, Volume 5, No.1, Juni 2018.

Afzalurrahman, Doktrin Ekonomi Islam, Jogyakarta : Dana Bhakti , 1996.

Ali, Mohammad Daud .Sistem Ekonomi Islam, Jurnal Zakat dan Wakaf

Didin Hafinuddin, Zakat Dalam Perekonomian Moder, Jakarta : Gema Insani, 2012.

Ali Yafie, Menggagas Fiqih Simbol Lingkungan Hidup, Asuransi Hingga Ukhuwah, Bandung: Mizan, Cet Ke-3, 1995.

Akbar, Nurullah. Dampak Pendayagunaan Dana Zakat Produktif Terhadap Keberhasilan Mustahiq (Studi Kasus Lembaga Manajemen Infaq Madiun), (Skripsi Universitas Airlangga, 2017.) 
Dewi Sundari Tanjung: Pengaruh Zakat Produktif Baznas Kota Medan |367

Al-Ghazali, Ihya' Ulumuddin, Jakarta: Republika, 2011.

Benedicta, Riyanti. Kewirausahaan dari Sudut Pandang Psikologi Kepribadian, Jakarta: Grasindo, 2003.

Chapra M. Umar. The Future of Economics : An Islamic Perspective, Sharie ah Economics and Banking Institute (SEBI), Jakarta : Kencana, 2001.

Dumasari Lubis, "Analisis Pengentasan Kemiskinan Di Kota Mea Jurnal Ekonomi dan Keuangan, 2015.

Departemen Agama RI , Alqur'an Terjemah Jakarta : Darus Sunnah, 2012. 2012.

Departemen Agama RI, Alqur'an Terjemah, Jakarta : Darus Sunnah,

Fahrudin, Pengantar Ksejahteraan Sosial, Bandung : Refika Aditama, 2012.

Garry Nugraha, Pengaruh Dana Zakat Produktif Terhadap Keuntungan Usaha Mustahiq Penerima akat. Semarang : Pustaka Sinar Harapan, 2011.

Ghozali Imam. Aplikasi Analisis Multivariete Dengan Program IBM SPSS 23, Semarang : Badan Penerbit Universitas Diponegoro, 2016.

Hafidhuddin, Didin. Agar Harta Berkah dan Bertambah, Jakarta: Gema Insani, 2009.

Hastuti, dkk, Peta Upaya Penguatan Usaha Mikro/ Kecil di Tingkat Pusat Tahun 2003, Jakarta: Kerjasama Lembaga Penelitian Semeru dengan Kementerian Pemberdayaan Perempuan.

Hendry, Noor Faisal. Ekonomi Manajerial,Jakarta: PT Raja Grafindo Persada, 2007.

Hamidi, M.Lutfi. Jejak-Jejak Ekonomi Syariah, ( Jakarta : Senayan Abadi Publising,2003.

Hakim, Abdul, Pengaruh Dana Bantuan Langsung Masyarakat Terhadap Pnyerapan Tenaga Kerja dan Perkembangan Usaha Tani Padi Serta Kesejahteraan Keluarga Petani Kabupaten Kota di Provinis Nusa Tenggara Barat Dalam Perspektif Islam.Disertasi tidak diterbitkan Pascasarjana Universitas Airlangga. 
Irma Yuliani, "Pengaruh ZIS Terhadap Pertumbuhan Usaha Mikro dan Penyerapan Tenaga Kerja serta Kesejahteraan Mustahik di Yogyakarta", Disertasi, Universitas Sunan Kalijaga Yogyakarta, Tahun 2011.

Adi Warman, Ekonomi Mikro Islami, Jakarta : Raja Wali Pers Indonesia, 2008 .

Irma Yuliani,“Pengaruh ZIS Terhadap Pertumbuhan Usaha Mikro dan Penyerapan Tenaga Kerja serta Kesejahteraan Mustahik di Yogyakartaa", Disertasi, Universitas Sunan Kalijaga Yogyakarta, Tahun 2011.

Iskandar Muda, Muhammad Arfan. Pengaruh Jumlah Zakat Produktif, Umur Produktif.

Jemmy Rumengan, Metode Penelitian Dengan SPSS, Batam UNIBA Press, 2001.

Jalaluddin, Pengaruh Zakat Infaq Sadaqah produktif terhadap pertumbuhan usaha mikro dan penyerapan tenaga kerja serta kesejahteraan mustahik di Lombok Timur NTB. Disertasi, Surabaya: Universitas Airlangga, 2012, Tidak Dipublikasikan

Kiuntjojo, Metode Penelitian, Bogor: Ghalia Indonesia, 2008

Lailatun Nafiyah, Pengaruh Pendayagunaan Zakat Produktif Terhadap Kesejahteraan Mustahiq Pada Program Ternak Bergulir Baznas Kabupaten Gresik. Jurnal el-Qist, 2015.

M. Dawan Rahardjo, Islam dan Transformasi Sosial Ekonomi, Jakarta: Lembaga Studi Agama dan Filasafat, 1999.

Muhammad Nafik, Ekonomi Ziswaq (Zakat, Infaq, Shadaqah dan Waqaf ), Surabaya : IFDI dan Cenforis, 2008.

Naqvi, Syed Nawab Haider. Ethics and Economics: An Islamic Synthesis. (The Islamic Foundation), 2003.

Nafiati, Pemberdayaan Mustahiq Melalui Pendayagunaan Zakat Produtif (Studi Kasus Baitul Maal Hudatama Peduli Semarang Tahun 2011). Skripsi Tidak Diterbitkan, Sleman : FE Universitas IAIN Walisongo, 2012. 
Dewi Sundari Tanjung: Pengaruh Zakat Produktif Baznas Kota Medan |369

Purmono, Sjechul Hadi. Pendayagunaan Zakat Dalam Rangka Pembangunan Nasional, Jakarta : Pustaka Firdaus, 1992.

Qadir, Abdurrahman. Zakat dalam Dimensi Mahdah dan Sosial, Jakarta: PT Pustaka Litera Antar Nusa, 2011.

Qadir, Abdurrahaman. Zakat Dalam Kondisi Mahdhah Dan Sosial) , (Jakarta: PT Raja Grafindo, 2011.

Robert Chambers, Proverty and Livelihoods: Whose Reality Counts?, Environment and Urbanization, 1995.

Shinta Dwi Windasari dan Ahmad Hendra ,SE, “Analisis Peranan Dana Zakat Produktif Terhadap Perkembangan Usaha Mikro Mustahiq (Penerima Zakat)",Jurnal Ekonomi, 2014.

Suharto, Analisis Kebijakan Publik, Bandung, Alfabeta, 2005.

Suharto, Kebijakan Sosial Sebagai Kebijakan Publik Peran Pembangunan Kesejhateraan Sosial dan Pekerjaan Sosial dalam Mewujudkan Negara Kesejahteraan di Indonesia, Bandung, Alfabeta, 2008.

Suryono, Sosiologi Suatu Pengantar, Bandung : Persada, 2014.

Sofyan Siregar, Statistik Parametik Untuk Penelitian Kuantitatif, Jakarta : Bumi Aksara, 2014.

Teguh Ansori, "Pengelolaan Dana Zakat Produktif Untuk Pemberdayaan Mustahik Pada Lazismu Ponorogo, Jurnal Muslim Heritage, 2018.

Utami, Siti Halida. Irsyad Lubis ,"Pengaruh Pendayaangunaan Zakat Produktif Terhadap Pemberdayaan Mustahiq Kota Medan”, Jurnal Ekonomi dan Keuangan.

UU No.38 Tahun 1999 Tentang Pengelolahan Zakat, Bab V ( Pendayagunaan Zakat) Pasal 16. 
UU No.23 Tahun 2011 Tentang Pengelolahan Zakat, Bab III ( Pendayagunaan Zakat ) Pasal 27.

UU No.11 Tahun 2009 Tentang Kesejahteraan Sosial, Bab I ( Ketentuan Umum ) Pasal 1.

Zadjuli, Suroso Imam. (2006). Makalah Seminar Evaluasi Ekonomi Syari'ah 2005 dan utlook 2006, CIEBERD, Surabaya: Universitas Airlangga. 